\title{
Implementation of Inquiry-based Learn- ing Supported by Digital Technologies in Courses of Professional Development for Chemistry Teachers
}

\author{
Zita Jenisová $^{1}$ Jana Braniša $^{1}$ Janka Melušová$^{2}$ \\ ${ }^{1}$ Department of Chemistry, Faculty of Natural Sciences, Constantine the Philosopher \\ University in Nitra, Slovak Republic \\ ${ }^{2}$ Department of Mathematics, Faculty of Natural Sciences, Constantine the Philosopher \\ University in Nitra, Slovak Republic
}

\begin{abstract}
Inquiry-based learning (IBL) is based on students` enquire of different situations and formulate relating questions. Experimental activity from real-life chemistry using school-measuring equipment containing spectrometer connected to computer was piloted with 25 in-service teachers attending course of professional development in chemistry. Sufficient computer literacy was assumed for the target group. Spectra of known colourings were compared to spectral characteristics of chosen samples from usual food. This laboratory activity should lead to development of science competences and willingness of teachers to deal with tables and graphs. Interviews with participating teachers showed their higher self-efficacy in implementing IBL with support of ICT in their teaching.
\end{abstract}

Keywords: inquiry based learning, digital technologies, lifelong learning, interview

\section{Introduction}

In terms of school science learning system, the system of methods of cognition that takes into account work processes, which bring us to new knowledge, is fun- damental. One of these is an empirical approach to cognition that starts with observation, experiment or measurement. The essence of inquiry-based learning is in an effort to attract the interest of students for the world and ideas around them.

According to the NCTM (2000), the inquiry learning is "a multifaceted activity that involves systematic observation, questioning, searching for information in books and other sources, comparison with known results of experiments using different tools for collecting, analyzing and interpreting data, formulating answers, explanations and predictions, and presentation of results. Inquiring requires identification of assumptions, use of logical thinking and consideration of other alternatives, explanations". (p. 23, cited in [1]) In active cognition, or by utilizing the inquiry-based learning in the subject of Chemistry, students are expected to gradually acquire the explanation of the course of chemical processes, or laws by themselves [1]. There is a change of roles in the classroom. Students ask questions, make decisions, propose the procedure of the experiment, discuss, collaborate, present results and provide reasoned answers and explanations.

Chemical experiment is one of the methods to eliminate formalism in the 
learning of Chemistry. It is an entertaining insight into the structure of matter and the secrets of microcosm. Experimentation leads to the discovery of a problem and to formulation of hypotheses [2]. It has an irreplaceable role in the learning of Chemistry. By its means, students are led to the solution of problems and to the correct formulation of hypotheses, thus students acquire knowledge. They create a supply of sensory experience for further learning, or life.

\subsection{Inquiry-based learning and digital technologies}

The criticized instructivistic (transmissive) approach to teaching in schools is characterized by a dominant teacher and a receptive passivity of students. Knowledge is acquired in a form that virtually eliminates the subsequent application and exploitation. Students cannot use their knowledge in specific situations, because they cannot recognize their relationship to reality [3].

The inclusion of school chemical experiments related to the school measuring systems allows for creation of a concept, which actively engages students in conducting experiments and supports their own creativity and unique approach.

Computer-based laboratories have undergone a certain development in Slovakia. Currently, the most widely used are LabQuest and Coach [4]. The declared positive aspect of these measurement systems in school practice is that they streamline the acquisition, recording and analysis of data. Entire process is faster and more opportunities for discussion and creation of logical connections remain, thereby increasing the science literacy of students. In relation to the learning process, they assist in making difficult and abstract concepts more easily discoverable, comprehensible and improve the achievement levels of cognition.
The connection between the inquirybased learning and the necessity of implementation of issues chemistry of everyday life has been accepted in the design of experimental activities focused on the use of computer-based laboratory. Therefore the problem of color additives in food and measuring system with LabQuest line interface spectrometer were selected as suitable. The presented experiment was implemented in the content structure of the education of Chemistry teachers, which is being currently implemented by The Department of Chemistry as a part of the project PRIMAS. The experiment was included in the topic of "Chemistry of consumables".

\subsection{Color additives and the UV/VIS spectrophotometry}

Dyes became the center of interest for confectioners and chefs even in the past. They were trying to use them to improve not only flavor and aroma of the food, but also to diversify and "beautify" their visual attribute. In the food industry colorants are divided into three categories. The first group consists of natural colors (caramel, chlorophylls and carotenoids); the other is synthetic color additives identical to natural. The third category consists of synthetic food color additives [5].

In recent years, there is a drastic reduction of the use of synthetic color additives, which are mainly used for food coloring, considering the high incidence of allergies, cancer and other types of irreversible diseases [6].

The easiest method to identify colorants is the UV / VIS spectrophotometry, i.e. the measurement of the absorbance at different wavelengths, generally selected so as to match the maximum absorption of the individual components. The experiments were designed so that participants of the study identified the color additive occurring in food of an ordinary consumer, namely a candy floss (Fig. 1), 
which is a favorite snack of many children. Subsequently, they compared unknown mixtures of color additives with obtained spectral characteristics. The procedure for the determination of an unknown pigment in candy floss was modified so that it can be implemented in school conditions with common laboratory equipment and a computer-based laboratory.

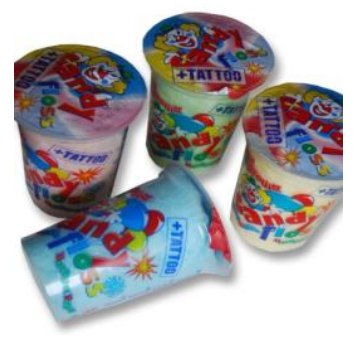

Fig. 1: Candy floss.

\section{Implementation of experimental work}

Instructions of the implemented experiment were drawn up in the form of a worksheet. It included essential items such as: the material, equipment and work practices, as well as the suggestions for different tasks and introduction into the problem of color additives and their identification for the student, and promotion of the reading of graphs, hence the development of key mathematical competence. The working-out of the primary tasks was followed by the implementation of the experiment itself.

With regards to the focus, simplicity and utilization of the experiment, the following ingredients were selected: water (solvent), candy floss (e.g. blue), artificial color additive E133 (Fig. 2). Tools were LabQuest and SpectroVis Plus interface, beakers, tubes, glass rods. The procedure was as follows:

A small amount of candy floss was dissolved in water in the first beaker. Blue artificial colors E133, E131, E132 were dissolved in water in the second beaker. Separately, by trial and error, the correct concentration of the color additive was diluted. A great care must be taken so that absorbance of solutions ranged from 0.1 to 1 absorbance units (AU). In case that it was not so, the solution must be diluted by solvent. Three cells were prepared: one with blank, one with candy floss solution and one with the solution of corresponding color additive. The measurement may be performed after the calibration of interface with blank.

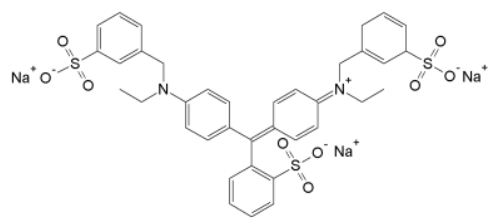

Fig. 2: Chemical formula of E133.

The task for the students was to measure and compare the absorption spectra of solutions and verify that candy floss indeed contains the artificial color additive, or if graphic outputs do not match with others, e.g. natural color additives. They determined the absorption maximum of an aqueous solution of the two samples is $629 \mathrm{~nm}$. Thus by comparing the measured spectra, they were able to confirm or deny their initial hypothesis that the blue colorant E133 is present in candy floss (Tab1).

In this case, the experiment was also supplemented by different colors and of course, the foods that might contain artificial colorings. Yellow candy floss contains colorants E102 and E110, red contains E129, green colored candy floss is a mixture of yellow and blue food color additives. Finally, the experiment may be, 
Tab.1. Measured absorption spectra of samples

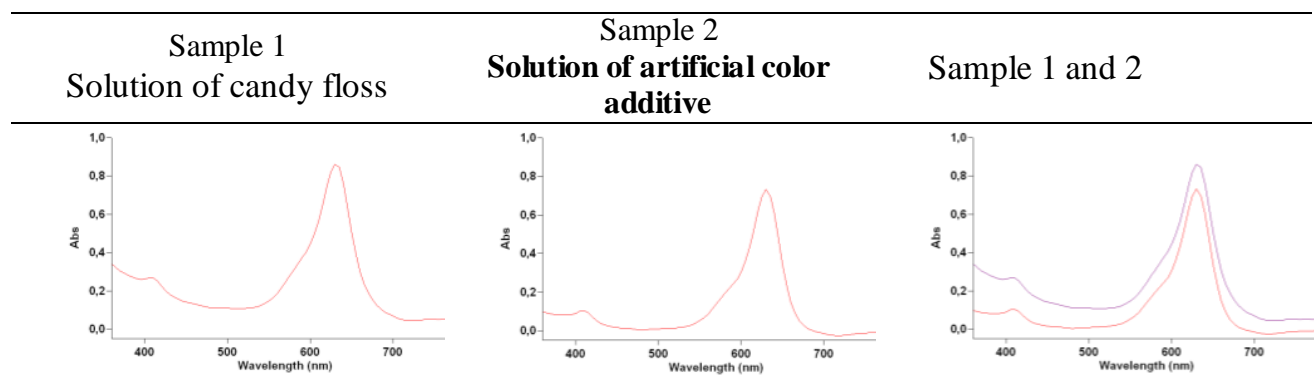

completed by an unknown sample - a mixture of several colors that may be measured on the basis of identified absorption peaks. As part of worksheets that are used to develop theoretical knowledge and skills of students, there are tasks, in which with the help of available literature or a web browser, students may summarize information about the color additives (E133, E131, E132, E102, E110, E129), their names, uses, impact on the body, the chemical composition (formula) or the maximum permissible daily dose. For example, the above-identified color additive E133 is also called Brilliant Blue. It is a synthetic blue color additive, well solvable in water and used for coloring candy, ice cream and beverages. By penetrating into the bloodstream, it interferes with cellular metabolism; it is not suitable for people with allergies and hyperactive children (ADHD). Finally, after processing of materials it was possible to state the following: "It is ironic that candy floss, while being especially inappropriate for children as it contains the synthetic color additive, attracts predominantly juvenile population."

\section{What about teachers?}

Proposed experiments, as well as methodologies, experiment implementation and, of course, prepared worksheets were presented to and pilot tested by teachers of all types of schools, who participated in the further education course as a part of an international project PRIMAS, which is focused at the inquiry-based learning. That was the reason, why they were addressed and participated in a small (25 respondents) didactic survey in the form of an interview, i.e. answering several questions. Based on the survey, it may be noted that the experiment, as well as the selected method had a positive response. The following questions were given to the participants of the survey:

- What is your assessment of the presented experiment carried out with the support of DT?

- What do you think that the reaction of your pupils to this style of work (inquiry-based learning) shall be?

- What is your opinion on the usefulness of the prepared material (experiment, worksheet, etc.) at your school?

- Would you implement the experiment in your lessons, if you had the necessary laboratory equipment?

In their answer to the first question, the participants clearly stated that computeraided laboratory streamlines the laboratory work (e.g.: reduction of the execution time of experiments); it develops students' ability to correctly read data 
from graphs, as well as interpret this type of output. Digital technologies are considered an incentive for students. In the second question, most of the teachers expressed the view that the evaluation of spectra by their comparison shall not be problematic for students, but they shall have difficulties to identify the problem and to propose a solution as students are not well accustomed to the inquiry-based learning and they do not have sufficient experience. They suggested that students may be helped by questions, proposing hypothesis and discussion management. A small number of participants $(16 \%)$ expressed their concern that for some students the inquiry-based learning may not be suitable. The next question dealt with pilot presented materials. Here, the answers were consistent with the statement that these materials were of interdisciplinary nature (chemistry, physics and mathematics) with the exploitation of the chemistry of everyday life. They also stated that all these are simple, time and cost effective experiments. As for the last question, $72 \%$ of teachers welcomed this experiment, $20 \%$ even considered it necessary. One of the respondents answered reluctantly and only one considered it as useless.

\section{Conclusion}

The inquiry-based learning combines posing questions, making independent decisions, designing procedures for handling of laboratory experiments, discussion, collaboration, presentation of results, explanations and justifications of answers. All these activities were incorporated into materials created by the Department. The ambition is to develop scientific literacy of students in Chemistry through inquirybased learning, in which charts became the dominant visualization components. The results of interviews indicate that incorporating new experiments, with the support of DT, into the teaching process in practice may meet with a positive response and shall develop not only scientific, but mathematical competence as well.

\section{Acknowledgement}

This work was conducted under 7FP project PRIMAS, GA 244380.

\section{References}

[1] S. Čeretková, "PRIMAS guide of supporting actions for teachers in promoting inquiry-based learning", Freiburg: University of Education, 77p., 2011

[2] L' Held et al, "Výskumne ladená koncepcia prírodovedného vzdelávania (IBSE v slovenskom kontexte), " Bratislava: Veda, pp.138, 2011. ISBN:978-80-8082-486-0.

[3] M. Bílek, M. Klečková, “K možnostem inovace výuky chemie na základní škole $\mathrm{v}$ době kurikulární reformy," In: D. Kričfaluši, D. (ed.) Aktuální aspekty pregraduální připravy a postgraduálního vzdéláváni učiteli chemie - sborník přednášek z mezinárodní konference. Ostrava: PřF OU, pp. 13 - 16, 2006.

[4] S. Hrašková, B. Brestenská 'Digitálne kompetencie učitel'ov chémie na Slovensku, Technológia vzdelávania, Roč.19, č.7,pp. 8-12,2011

[5] P. Stratil, "ABC zdravé výživy," Brno: pp 348,1993.ISBN 80-9000298-6.

[6] O. Paredes-Lopez, "Molecular Biotechnology for Plant Food Production, "Technomic publishing company, pp. 6-466, 1999. 